\title{
The Roles of Local Government in Preventing Woman Trafficking in Laws No 21 of 2007 Perspective That Concer to Crime of Human Trafficking in District of Bone
}

\author{
Nur Paikah ${ }^{1}$ \\ ${ }^{1}$ Lecturer, State Institute for Islamic Studies Bone, Indonesia
}

\begin{abstract}
:
This research aims to analyze the process the role of government of human trafficking. Research wasconducted at Bone Regency. Methods used the case study method by using a qualitative approach. Theresults showed human trafficking is one of the crimes against humanity, because this act has violated humanrights, and the majority are victims of women and children. Referring to the Law that, every human being,especially women and children, has the right to live peacefully and properly as they should. Therefore, theright of life of every human being cannot be reduced by anyone and under any circumstances including notallowed to be traded, especially women and children. This is where the role of the government, especiallythe local government of Bone Regency, seeks to guarantee the protection of positive rights for them for theirlives. In this case the local government of Bone Regency provides protection and prevention of humantrafficking, especially women and children as a form of respect, recognition and protection of human rightsis stated explicitly in Article 58 of Law Number 21 of 2007 concerning Crime of Trafficking in Persons.
\end{abstract}

Keywords: Government, Trafficking and Women

\section{Introduction}

Everyone has the right to survival, growth and development and is entitled to protection from violence and discrimination. The right to life of every human being cannot be reduced by anyone and under any circumstances including not traded such as human trafficking, especially trafficking in women (Women Trafficking) (Farid, 2009).

According to Hull and Jones (1997) that (human trafficking human trafficking) is one of the crimes of humanity, because clearly this problem violates human rights, and is most vulnerable to women and children. As for some examples of human rights violated including, the right to life; the right not to be tortured; the right to freedom and security of himself.Human Trafficking,human trafficking or what is often referred to asin Indonesia, has recently been widely discussed in the mass media, although in fact in both feudal and colonial times this is not an issue considered important in the life of the nation.

At present the issue of trafficking is still one of the major threats where every year almost thousands of women and children must become victims oftrafficking. According to data released by the International Organization for Migration (IOM), cases of human trafficking in Indonesia are even more astonishing. Data released in 2015, Indonesia ranked top with 3,943 victims of human trafficking. In addition, at least $90.3 \%$ of victims of trafficking in persons are women and $23.6 \%$ of children, who are vulnerable to violence (Hull and Jones, 1997).

The development of human trafficking in Indonesia has come to the attention of the international community and international organizations, especially the United Nations. The attention of the United Nations can be seen from the birth of the Protocol to prevent, prosecute and punish trafficking in persons, especially women and children (Protocol To Prevent, Suppress And Punish Trafficking in Persons, Especially Women And Children) as one of the protocols resulting from the United Nations Convention The Nation Against Organized Transnational Crime (United Nations Convention Against Transnational Organized Crime) on 
December 12-15, 2000 in Palermo (Martin and Miller, 2009). Then it was clarified by the Government of Indonesia in Law Number 21 of 2007 concerning the Eradication of Trafficking in Persons to Prevent and Eradicate Crime of Trafficking in Persons, and is supplemented by Presidential Regulation Number 69 of 2008 concerning the Task Force for the Prevention and Handling of Criminal Trafficking in Persons Chaired by the Coordinating Minister of State for People's Welfare, the Daily Chairperson is the State Minister for Women's Empowerment and Protection of the Republic of Indonesia Child and 19 Cross Ministry Institutions as members of the Task Force.

For Indonesia which is a developing country, it is difficult to avoid the issue of human trafficking. Indonesia with a population of up to 2016 is around 253.60 million people, which extends between two continents and two oceans, influencing the development of transboundary crime (BPS, 2016). Very wide access from land, sea and air both into the country of Indonesia and also coming out, enlarging the development of human trafficking. This makes Indonesia a sending or source country (Department of Justice, 2002).

So complex is the problem of trafficking in Indonesia, it is possible for every region in Indonesia to have the potential for trafficking, especially in Bone District (The Human Right Watch, 2015). In Bone District, based on a report from the Manpower Supervisory Agency, it was confirmed that trafficking in Bone Regency basically exists, although there is no concrete and clear data, but there are indications of trafficking in practice and its activities are hidden and the work procedures are very neat because they are supported by sophisticated technology and neat organization.

This is also the background of the South Sulawesi Provincial Government to Establish Labor Inspectors placed in Bone Regency by supervising 5 Regencies, namely Bone, Wajo, Soppeng and Sinjai Regencies. One of its functions is to supervise the workforce, especially the fulfillment of human rights at work, including freedom from exploitation / slavery which leads to the practice of trafficking. The practice of trafficking in women in Bone District is indicated through the process of migrant workers abroad, who were initially placed to work in cafes and warkop, and most of them were girls. Cafe and warkop are the initial recruitment period for the chain of trafficking of women in Bone Regency (Mardiana, 2017).

This is relevant to the number of workers in Bone Regency for 2016 as many as 388,410 workers, and around $80 \%$ are female workers with a range of 4,656 people (Mardiana, 2017). Of course it is worth watching for the potential of women's trafficking with the mode of accepting female migrant workers, or sending domestic domestic helpers.

This expression is of course not excessive, given the recruitment process through giving dishonest information or because it utilizes economic conditions and the crush of life causes the victim to voluntarily work, for those who have not fulfilled the requirements to work temporarily employed at the cafe until considered sufficient to meet the requirements for departure and sometimes getting undue wages by reason of field work practices. This is corroborated by data from the Provincial Manpower Supervisory Agency, that in Bone Regency in 2016, around 6 people were predicted to be brought abroad in trafficking mode, and currently there are around 20 women who are indicated to be prepared to be sent abroad, and currently still being guided and trained to be professional servants in cafes, restaurants and coffee shops both voluntarily because the mode of earning wages earlier or even or due to economic factors (Mardiana, 2017). Although there has been no information about whether they will actually be sold or not. But it is still in the process of strict supervision from the labor inspector of Bone Regency.

\section{Theoretical Background \\ Definition of Women's Trafficking}

Etymologically the term trafficking comes from the English language and means "illegal trade" or illegal trade. Talking about human trafficking is closely related to slavery and slavery-like actions that have been banned through out the world (Lapian, 2006). On that basis, trafficking: recruitment, shipping, transfer, shelter, or acceptance of someone, with threats, or the use of violence, or other forms of coercion, kidnapping, fraud, fraud, abuse of power or vulnerable position, or member, or accept payment or benefit to obtain permission from people who have authority over others, for the purpose of exploitation (Kartika, 2008).

In terms of terminology, the notion oftraffickinghas a different meaning for everyone. Trafficking in persons includes a complex set of problems and sensitive issues that are interpreted differently by each person, depending on the personal or organizational perspective. 
The first definition of trafficking is formulated by the ODCCP (Office for Drug Control and Crime Prevention), namely: "as recruitment, transfer, delivery, placement or acceptance of minors for exploitation purposes and that uses threats, violence, or other coercion such as kidnapping, fraud, fraud, abuse of authority or important positions. Also give or receive money or assistance to get approval from the person who has full control.

According to the Coalition Against Traffic in Women, trafficking in women is the recruitment or transfer of people by other parties using violence, threats, the use of violence, abuse of power or dominant position, fraud or all forms of violence, for the purpose of exploiting people sexually and economically for profit other parties such as recruiters, pimps, traffickers, brokers, brothel owners (Hughes, 2003).

From the above elements, it clearly alludes broadly to the notion of trafficking, so this shows that the Protocol on the Prevention, Punishment and Eradication of Trafficking in Persons in particular Women and Children is a complement to the United Nations Convention on Against Organized Transnational Crime in 2000, which was clarified by Indonesia in Act No. 21 of 2007 concerning the Prevention and Eradication of Crimes in Trafficking in Persons, succeeded in formulating a fairly comprehensive definition of the issue of trafficking in which this matter will be more effective and more able to answer the issue of trafficking in women (Law Number 21 of the year 2007).

\section{Trafficking of Women as a Global Problem}

Women have long been active in economic and social activities as farmers, traders, workers (in the informal sector), and as housewives. However, most women have not enjoyed the same respect and respect as men according to their contributions and workload (Sadli, 2015). In patriarchal societies, gender-based division is the role between men and women and then places women in a subordinate position.

The presence of development causes more violent oppression for women as a result of that position. This is mainly because the development carried out is nothing but an expansion of wealth creation projects according to the modern economic theory of western patriarchy which extorts and removes women (Shiva, 1999). Therefore, development should be understood as a political sex economy that is appropriately understood if the relationship of sexuality, marriage, and familial relations with economic relations and capital accumulation are traced in various levels of human relations, namely family, community, state and even interstate relations (Shiva, 1999)

In the concept of development, women are forced to participate unequally. While there are many female populations, the gender-based division of labor causes women not to be counted as breadwinners. International Divition of Labor takes into account women only as a reserve army, which can be used easily at any time, and as such is easily disposed of if it is no longer needed or when an economic crisis occurs. In addition, the marginalization of women is also carried out through the selection of jobs that are as if specifically for women based on the roles that are attached to their reproductive functions, or more commonly referred to as the International Sexual Devition of Labor.

Marginalization of women in this world capitalist system, then causes women to have only very limited choices in fighting for economic improvement, especially because of the subordinate position that makes it difficult for women to acquire skills and education that they can put forward to compete in the labor market.

\section{Factors Human Trafficking and the Impacts}

The factors of trafficking as already done by the United Nations Global Initiative to Fight Human Trafficking are: Gender-based violence; discriminatory labor practices; patriarchal social structure; waning family ties network; marginalization of ethnicity, race and religion; corrupt and failed government; status issues (as citizens or legal settlers related to work); the role and position of women in the family; hierarchy of power and social order; responsibilities and roles of children; early marriage the high rate of divorce and the social stigma that accompanies it; damage to personality development; limited achievement or educational achievement; and limited economic opportunities.

But the notion that poverty is something that causes trafficking is not entirely wrong. Poor people in developing countries do not have many choices in their lives, and therefore they seem to be "forced" to leave their hometowns or communities in order to survive or to seek better opportunities economically in a place or country other. 
Referring to the United Nations Development Index, reportstates that it turns out that countries of origin ofvictimstrafficking actually come from middle-level countries and are not the main target ofvictimstrafficking who were allegedly originally.

The targets that are vulnerable to being victims of trafficking in women and children include:

1. Street children.

2. People who are looking for work and do not have the correct knowledge of information about the work to be chosen.

3. Women and children in conflict areas and those who become refugees.

4. Poor women and children in cities or rural areas.

5. Women and children in the border region between countries.

6. Women and children whose families are in debt.

7. Women victims of domestic violence, rape victims.

The consequences arising from the practice of trafficking in persons, especially women and children, are:

1. Women experience physical and mental violence even though sometimes there are not many actual situations of trafficking in persons, such as domestic servants who have not been paid for years. Mental violence occurs when the victim is isolated from the outside because he cannot connect with family, friends or the opposite sex. Get a curse that humbles his human dignity. Physical violence has occurred when a person must work outside working hours, beaten, grabbed in addition to clearer forms such as rape.

2. Women as part of society are increasingly marginalized as victims of trafficking, because there is no respect for the basic human rights of women, especially human rights.

3. As a result of violence, extortion, especially coercion against women to have sexual intercourse, creates very deep and lasting suffering throughout their lives and damages the future to survive a woman.

4. Resulting in women and girls trapped in prostitution business.

5. The stigmatization imposed on women and children who have been exploited in prostitution, for example, is a severe obstacle for victims to be able to participate in development and community life.

The impact caused by trafficking has a huge impact on the life and future of women and children, women and children feel that they are no longer valuable because their human rights have been taken away. They also have to accept various kinds of bad stigma from the community, and because of that stigma can also hamper their psychological development and social life.

\section{Research Results and Discussion Regional Government Role In Preventing Trafficking in Bone regency}

Trafficking(humantrafficking)is a crime against humanity, because obviously these problems violate human rights. One example of human rights violated is the right to life, the right not to be tortured, the right to freedom and security of himself with the aim of exploiting or causing exploitation.

Human trafficking is vulnerable to women and children. Data on trafficking of women and children shows an increasing trend along with the increase in transportation facilities, sophistication of electronic facilities, globalization, the loss of conscience to the commercial benefits of commercialization. Several cases included, in Kudus six female sellers were arrested by the ranks of the Holy Police, the victims had been forced to become commercial sex workers in Kalimantan for two weeks. Initially they were hired in supermarkets in Pangkalambun Kalimantan and were promised a monthly salary of 10 million-15 million.

Responding practices trafficking to the hidden in Bone Regency through informal company services, it was believed by the Head of the Women's and Child Empowerment Office of Bone Regency that the reality was The field has so far shown that women trafficking is basically there, but victims and their families are reluctant or afraid to report to the authorities and NGOs to get assistance, in various ways the perpetrators are close relatives, do not have adequate legal understanding, are threatened by perpetrators and other things.

This is where the role of the central government, especially the local government of Bone Regency, is the spearhead of the state in providing guarantees for the protection of their positive rights for the sake of a bright life in the future. Moreover, in general, the protection and prevention of trafficking in persons, especially women and children as a form of respect, recognition and protection of human rights are 
expressly stated in Article 58 of the Law Number. 21 of 2007 concerning the Crime of Trafficking in Persons (TPPO), stated that:

1. To carry out the eradication of trafficking in persons, the Government and the Regional Government must take steps to prevent and deal with the crime of trafficking in persons.

2. To streamline and guarantee the implementation of the steps referred to in paragraph (1) the Government establishes a task force consisting of representatives from the government, law enforcement, community organizations, non-governmental organizations, professional organizations, and researchers / academics.

3. The Regional Government forms a task force consisting of representatives from the local government, law enforcement, community organizations, non-governmental organizations, professional organizations, and researchers / academics.

4. The task force referred to in paragraph (2) and paragraph (3) is a coordinating institution in charge:

a. Coordinating prevention efforts and handling criminal acts of trafficking in persons;

b. Carry out advocacy, socialization, training, and cooperation;

c. Monitoring the progress of the implementation of victim protection includes rehabilitation, repatriation and social reintegration;

d. Monitor the progress of law enforcement implementation; and

e. Carry out reporting and evaluation.

5. The central task force is led by a minister or minister-level official appointed by presidential regulation.

In Article 56 above, affirms the need for the Eradication of Crimes against Trafficking in Persons by requiring the government and regional governments to take precautionary measures and handle criminal acts of trafficking in persons. Thus the protection of women and children from acts of trafficking includes prevention efforts to prevent acts of trafficking in women and children. As well as efforts to deal with acts of trafficking. In addition, concrete steps are needed in the form of task forces, advocacy, socialization, training and cooperation and active participation of the community.

\section{Efforts Taken by Local Governments in Preventing Trafficking in Women in Bone Regency}

Solutions to solvingproblemstrafficking can not only be done by individuals or groups, but it requires strong awareness and cooperation among all parties, both individuals, groups at the local, national and international levels. There are several solutions that can be done to prevent the occurrence of human trafficking and at the same time the possibility of being considered in preparing specific policies in the context of the emergence of new issues that cannot be accommodated by existing laws, including:

1. At the community level

a. Providing labor-intensive training to the community - communities that do not have the ability to increase the economy of the community.

b. Providing knowledge about Human Trafficking to communities.

c. Improve inter-community relations so that there is no mutual benefit for their own interests.

d. Introducing or providing counseling to communities about the modes commonly used by traffickers.

2. At the level / level of the National

a. Enforcement of Law Number 21 of 2007 concerning the Eradication of Crimes of Trafficking in Persons.

b. Improve security of safeguards on national borders, both land and sea.

c. Increasing security at immigration (overseas permission).

d. Increase employment.

e. Improve education.

f. Closing discos and cafes that are sexual exploitation.

g. Providing training to CSWs who were arrested so that they would not return to a dark world.

h. Give as much punishment as possible to traffickers.

i. Improve the economy of the small people.

j. Hold a two-child program better.

3. At the international level / level 
a. Increasing cooperation between countries to eradicate trafficking in persons.

b. Conduct joint operations to eradicate trafficking in persons.

c. Form an organization to combat trafficking.

To minimize the existing constraints in preventing trafficking in women in Bone Regency, efforts must be made so that Law Number 21 of 2007 concerning Prevention of Crime in Trafficking in Persons in Bone Regency can be realized optimally, among others:

1. There needs to be a strengthening of Law Number 21 Year 2007 concerning Prevention of Trafficking in Persons in the form of a regional regulation because the law is general and must be adjusted to the conditions and culture in which the person with disability is located. For this reason, the Bone Regency Government needs to immediately issue provisions that strengthen Law Number 21 of 2007 concerning Prevention of Trafficking in Persons in the form of Bone Regulations so that it can become a clear legal umbrella for all parties and especially for women and children in Bone District, so that their rights become clearer.

2. Bone Regency Government may form a task force in preventing and eradicating the crime of trafficking in people in Bone Regency, especially female trafficking so that all members of the task force can play an effective role in preventing and eradicating the crime of trafficking in the

3. Bone District Government in this case the Women's Empowerment Service and the Office of Manpower and Transmigration of Bone Regency needs to collaborate with all parties involved in this case the Population and Civil Registration Service, the Social Welfare Service, the Health Service, the Police and the Prosecutors and the Education Office to be able to cooperate as soon as possible to socialize Law Number 21 of the Year 2007 concerning Prevention of Trafficking in Persons and Pepres Number 69 of 2008 Concerning the Task Force for the Eradication and Prevention of Trafficking in Persons to all parties in Bone Regency more intensively, so that all parties know and understand that they have a necessity to prevent the widespread practice of trafficking in persons, especially women in Bone Regency.

4. The Bone District Government must encourage the availability of adequate facilities and infrastructure, including an increase in the budget related to the prevention and eradication of trafficking in persons, especially women and children.

5. The need for supervision and assertiveness from the government so that Law Number 21 of 2007 concerning Prevention of Crime in Trafficking in Persons can be implemented properly, so that all parties can fulfill their obligations properly and victims and their families get their rights in all fields. In addition, supervision is also needed from third parties such as women and child observers organizations, which serves to monitor and supervise the government's performance in this case the Office of Women's Empowerment and Child Protection and the Manpower and Transmigration Office of Bone Regency in preventing trafficking in persons, especially women and child.

\section{Conclusion}

The role of Bone District Government in preventing and eradicating the crime of trafficking in persons is still very low. One of the factors is the lack of political Bone District local government in issuing Regional Regulations concerning Prevention and Eradication of Criminal Trafficking in Persons so that the legal umbrella used still refers to the provisions in Law Number 21 of 2007 concerning Prevention and Eradication of Crimes in Trafficking in Persons. In addition, the Task Force for Prevention and Eradication of Trafficking in Persons in Bone District has not yet been established as mandated in the Presidential Regulation of the Republic of Indonesia Number 69 of 2008 concerning the Establishment of Task Force in Preventing and Combating Crime in Trafficking in Persons, as a consequence of the prevention of trafficking in persons. because there is no good cooperation system.

The efforts taken by the Bone Regency government in preventing and eradicating the crime of trafficking in persons are improvements to the legal system which includes three things, namely the improvement of legal substance by immediately issuing regional regulations as a legal umbrella in the effort to prevent and eradicate the crime of trafficking in persons, especially women and children. in Bone Regency, in addition, it immediately issued Regent Regulations for the Establishment of Task Forces to Prevent and Eradicate Crime of Trafficking in Persons, especially Women and Children. Improvements in the legal structure sector in this case intensely socialize the importance of preventing trafficking in persons, especially women and 
children to the apparatus and the community, of course, supported by the availability of an adequate budget so that the socialization activities can be evenly distributed across sub-districts, villages and villages. The last effort is to persuasively approach the community to not be afraid to report problems that befall them to the officers while providing examples and exemplary in order to build a positive image of the apparatus in the eyes of the public so that they familiarize themselves without fear, shame or anxiety.

\section{References}

[1] Mohammad Farid. 2009. Perisai Perempuan, Kesepakatan Internasional untuk Perlindungan Perempuan. Yogyakarta, 2009.

[2] Hull, Sulistyaningsih dan Jones. 1997. Pelacuran Di Indonesia: Sejarah dan Perkembangannya. Jakarta: Pustaka Sinar Harapan, 1997.

[3] Philip Martin dan Mark Miller. 2009. Smuggling dan Trafficking: A Conference Report." International Migration Review.

[4] Badan Pusat Statistik Republik Indonesia.2016. LaporanBulanan BPS Data SosialEkonomi.

[5] S Department of Justice. 2002. Trafficking in Persons Report. Washington, 2010.

[6] The Human Right Watch. 2015. Global Report on Women's Human Rights. New York Human Right Watch.

[7] Wawancara Mardiana. 2017. Salah Satu Pengawas Ketenagakerjaan Kabupaten Bone.

[8] Gandhi Lapian. 2006. Trafiking Perempuan dan Anak: Penanggulangan Komprehensif Studi Kasus Sulawesi Utara. Jakarta: YayasanObor Indonesia.

[9] Sari Dian Kartika. 2008. Perdagangan Manusia Khususnya Perempuandan Anak Dalam Tinjauan Hukum" (makalah di sampaikan pada semiloka sehari Woman Trafficking dalam Perspektif Agama dan Budaya. Jakarta.

[10] Donna Hughes. 2003. Coalition Againts in Women :Trafiking and Prostitution in Asia Pasific.

[11] Undang-undang No. 21 Tahun 2007 tentang pemberantasan tindak pidana perdagangan orang.

[12] Saparinah Sadli. 2015. Ceramah untuk Forum Peduli Hak Asasi Manusia. Banda Aceh.

[13] Shiva. 1999. Kemiskinan Dunia Ketiga: Menelaah Kegagalan Pembangunan di Negara Berkembang. Jakarta: Pustaka Cisendo. 